論文・Paper

\title{
ピッチーカーボンブラック分散系の粘弾性
}

逆井基次・梅崎哲春・稲垣道夫

(豊橋技術科学大学 物質工学系)

\begin{abstract}
ピッチをマトリックスとし, 球形炭素粒子（カーボンブラック及びカーボンビーズ）をフィラー とする分散系の粘弾性特性をねじりクリープ法によって測定した。

カーボンブラックとしては平均粒径が $0.3 \mu \mathrm{m}$ でほぼ独立した粒子からなるサーマルブラックを 選んだ。また，比較のために，それを約 $3000^{\circ} \mathrm{C}$ まで加熱処理したもの，及び $37 \mu \mathrm{m}$ 以下の粒子か らなるカーボンビーズも用いた． $50^{\circ} \sim 80^{\circ} \mathrm{C}$ における定常クリープコンプライアンス及び定常粘度 を測定温度，フィラー容積分率の関数として決定した。粘度の温度依存性は直線で近似でき，流動 のための活性化エネルギーは, フィラーの種類, 量によらず $2.8 \times 10^{5} \pm 0.1 \mathrm{~J} / \mathrm{mol}$ であった. 粘度 の絶対値はフィラーの添加によって増大し，その増大の割合は特にカーボンブラックで顕著であっ た。これら分散系の粘度をフィラーの容積分率との関係で見ると，カーボンビーズ分散系の場合は ほぼ一般的な分散系の範囲に入るのに対して,カーボンブラック分散系は極端に大きな粘度を示す. カーボンブラックの場合粒子表面にかなり厚い吸着層が生じていることが示唆された.
\end{abstract}

(1985 年 7 月 29 日受付)

\section{Viscoelastic Properties of Pitch-Carbon Black Disperse Systems}

\author{
Mototsugu SAKAI, Tetuharu UMEZAKI and Michio INAGAKI \\ (Materials Science, Toyohashi University of Technology
}

\begin{abstract}
On pitch-carbon black disperse systems, viscoelastic properties (steady state creep compliance and viscosity) were measured at different temperatures of $50^{\circ}-80^{\circ} \mathrm{C}$ using torsional creep method. The carbon black used was a thermal black with an average particle size of $0.3 \mu \mathrm{m}$. For comparison, the $3000^{\circ} \mathrm{C}$-treated carbon black and a carbon bead with the particle size of less than $37 \mu \mathrm{m}$ were also used. The increase in viscosity caused by dispersing the carbon black was very much remarkable, much more pronounced than that by dispersing the carbon beads, which was discussed from a strong interaction between the matrix pitch and the filler carbon black, in other words, by the formation of thick adsorbed layer of the matrix pitch on the surface of the carbon black particles. Temperature dependences of viscosity of all of the systems examined were linear and gave the same activation energy of $2.8 \pm 10^{5} \mathrm{~J} / \mathrm{mol}$.
\end{abstract}

[Received July 29, 1985]

Key-words : Viscoelastic, Pitch, Carbon black, Disperse system, Rheology, Viscosity, Creep compliance

\section{1. 緒 言}

ピッチはいわゆる人造黒鉛材料製造の際のバインダー として古くから使われてきている。フィラーコークス粒 または粉末をバインダーピッチで权つ合したのち，押出 しまたは型込み成形する際には，そのねつ合物の粘弾性 的性質は極めて大切である。最近はまた，ピッチを原料 とする炭素繊維の製造技術が開発され, より安価な高性
能炭素繊維の製造法として注目されている。この製造工 程においても溶融ピッチの粘弾性的性質が紡糸プロセス に対して決定的影響を与えていると考えられる.

しかるに，ピッチについてのレオロジ一的研究は極め て少なく, ピッチそのものの粘弾性的性質が解明されて いるとはいえない. 粘度の測定は比較的容易であること もあって，ピッチの流動特性パラメーターとして広く採 
用され, 工場現場でも測定が行われている. しかし, 弾 性的性質はその重要性が指摘されながら, それが測定, 研究された例は極めて少ない. まして, ピッチをバイン ダーとしたねつ合物についてのレオロジー研究はさらに 数が少ない.

ピッチは広い分子量分布を持った縮合多環芳香族化合 物の混合物であって，明確な融点を持たない．工業的に はある規格に基づいた軟化点の測定が行われ，ピッチの 性状を示すパラメーターとして使われてきている。しか し，この軟化点は融点のような特性温度ではなく見掛け の流動特性の目安を与えているにすぎないことをさきに 示した ${ }^{1}$. ピッチは典型的なガラス生成物質であり，そ のガラス転移点がその粘弾性特性を示すうえで重要であ る.

著者らは，ピッチの溶剤を用いた分子量分別法を提案 し ${ }^{2)}$ ，その方法によって得られた分別ピッチについて粘 弾性特性の測定を行っだ?. その結果, エネルギ一散逸 の尺度としての粘度，および弾性的に蓄えられたエネル ギーの尺度としての定常状態コンプライアンスが強い分 子量依存性を示すことを明らかにした.また, ガラス転移 点の測定を行うことによって, そのレオロジーパラメー ターとしての重要性を示すとともに ${ }^{3)}$, 極限粘度および 拡散係数の測定を通してピッチ分子の形状および大きさ についても議論してきた ${ }^{1), 4), 5)}$. また，ピッチのブレン ドの粘弾性パラメーターへの影響についても実験的検討 を行ってきた1),3).

ピッチを用いたねつ合物についてのレオロジー的研究 は Bhatia(1),7) 及び Sakai' ${ }^{8,9)}$ によってなされた。

Bhatia は毛細管レオメーターを用いて，ねつ合物が 一定の降伏応力をもつビンガム物体として挙動し, それ に対するバインダーピッチ含有量の重要性を実験的に示 した ${ }^{6)}$. 更に, 彼はねつ合物が非二ュートニアン挙動を 示し，それがフィラーコークスの量によって強く影響さ れることを示した7). Sakai はピッチーコークス分散系 について，コークス含有量の広い範囲にわたる粘弾性の 系統的研究を行った ${ }^{81,91}$. 分散系の粘度はフィラ一の量 の増大及び粒子径の減少とともに大きくなるが，その温 度依存性は，フィラーコークス粒子の大きさや含有量に は独立で, ピッチによって決まる，また，コンプライア ンスはフィラー粒子径が小さくなるほど, そしてフィ ラ一量が $50 \mathrm{wt} \%$ 以上で著しい減少を示すことを明らか にした。

本研究では, ピッチをマトリックスとする分散系 (工 業的にはカーボンペーストと呼ばれている) についての 理解をより深めるため, フィラー物質として球形粒子で あるカーボンブラック及びカーボンビーズを選び，その 粘弾性特性の測定を礼じりクリープ法によって行った。

\section{1 試料}

\section{2. 実 験}

分散系のマトリックスとしてのピッチは, 石油系ピッ チ (Ashland 240) をベンゼン中に溶解させ不溶成分を ろ別したのち, ベンゼン溶液から凍結乾燥法によって回 収したベンゼン可溶成分を用いた。 その平均分子量は 508 ，ガラス転移点は $52.6^{\circ} \mathrm{C}$ であった。

フィラーとしてのカーボンブラックは平均粒子径が約 $0.3 \mu \mathrm{m}$ で，ほぼ独立した粒子からなるサーマルブラッ ク（三池＃20）及び比較のために，このサーマルブラッ クを約 $3000^{\circ} \mathrm{C}$ まで加熱処理したものを用いた。なお， これらのカーボンブラックは大きな比表面積を持つ（約 $\left.9 \mathrm{~m}^{2} / \mathrm{g}\right)$ ので, 分散系試料の調製の前に, $120^{\circ} \mathrm{C}$ の真 空中で 1 昼夜乾燥したのち, 窒素ガス中で保管した。

更に，粒径の影響を検討するため，サーマルブラック より粒径が約 50〜100 倍大きいフィラーとして $37 \mu \mathrm{m}$ 以下の球形粒子からなるカーボンビーズ (呉羽化学) も 用いた。

\section{2 分散系試料の調製}

分散系試料は，まず必要量のフィラーをベンゼン中に 超音波を用いて十分分散させたのち，その中へピッチの ベンゼン溶液を徐々に滴下，混合して調製した。混合後 も密栓付きフラスコ中で 1 時間以上超音波分散を続けた のち, 凍結乾燥を 10 時間行い, 更に真空乾燥を 1 昼夜 以上行うことによって, 溶媒として用いたベンゼンを完 全に除去した.

このようにして得られた試料は粉末であるので，一旦 ホットプレート上に置いたテフロンビーカー中で軟化さ せ，減圧下で十分脱泡させたのち，テフロン製の型に流 し込みディスク状に予備成形した。これを更に，ステン レス製のモールド中で 370〜 520 g の荷重を掛けながら 約 $100^{\circ} \mathrm{C}$ (軟化点の約 $10^{\circ} \mathrm{C}$ 下) に 75 分間保ち, 形を 整えた.このように調製された試片の直径は 10 または $15 \mathrm{~mm}$, 高さ 3〜7 $\mathrm{mm}$ である.

\section{3 粘弾性測定と解析}

粘弾性の測定には，図１に示すねじりクリープ測定装 置 $^{1), 3)}$ を用いた。 この装置の原理は, 上部のトーション ワイヤーを一定角度㸚じることによって一定のトルクを 発生させ，これを試片に加え単純ずり応力を発生させ， 時間とともに試片が㸚じれていく角度を測定するもので ある. 装置は大きく分けて, トルク発生部, トルク伝達部, 及び試片ホルダーの三つの部分から成っている。トルク 発生部ではプロトラクターを一定角度 $\theta$ 回転させて トーションワイヤー（径 $0.5 \mathrm{~mm}$, 長さ $1500 \mathrm{~mm}$ ) をね じることによって, 一定のトルク $k \theta$ を発生させること ができる.ここで，本装置のトーションワイヤーのねじ り剛性率 $k$ は $2.87 \times 10^{-3} \mathrm{Nm}$ であった.

発生したトルクはマイカレックス製のカップリング 


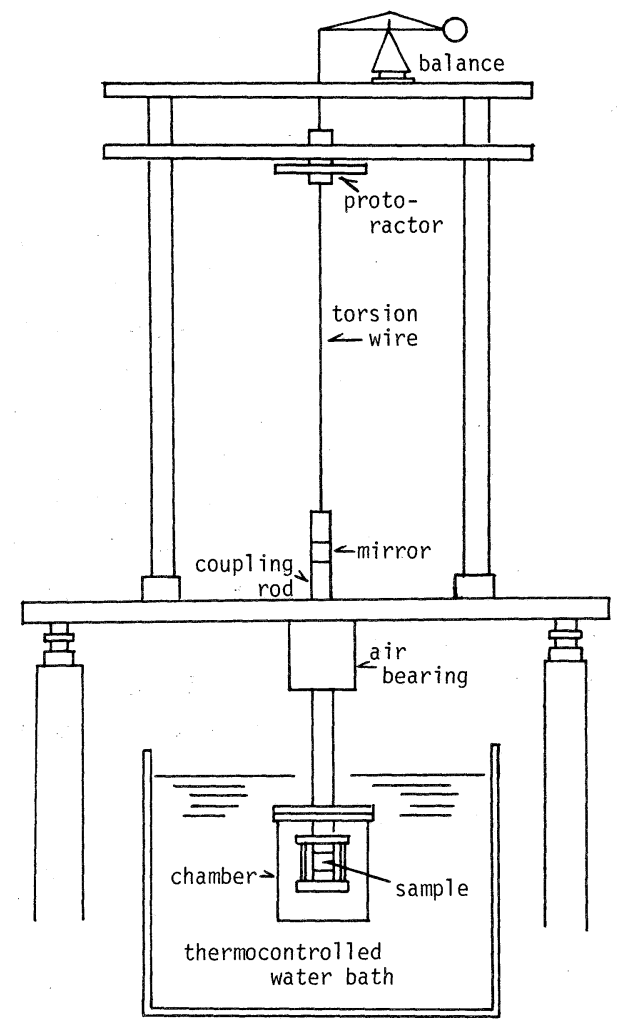

Fig. 1. Apparatus for torsional creep measurement.

ロッドを通して試片に伝達される。ロッドは十分に高い 剛性率と低い熱伝導率を持っており, 摩擦を生じないよ うにエヤーベアリングを用いて中心に保持されている。

円板状試片は上下面でステンレススチール製プレート に接着固定されている. 上部プレートはカップリング ロッドに固定されており，トルクを試片に加える. また， 下部プレートはサンプルホルダーを通して本体に固定さ れている. 一定トルク下での試片のねじりクリープは, カップリングロッドにつけた鏡を用いたレーザー光てこ 法によって，ねじり角度 $\alpha(t)$ として測定される。なお， 試片ホルダー全体は恒温水槽中に漬け, $\pm 0.05^{\circ} \mathrm{C}$ の精 度で一定温度に保たれている. また, 試片に余分の荷重 がかかったり，試片の熱膨張によって上下方向に力を生 じないように,トルク発生部, トーションワイヤー, カッ プリングロッド，及び武片に接着したステンレススチー ルプレートは本体上部に置いた天びんによってバランス されている.

単純称じりクリープコンプライアンス $J(t)$ は格じり 角度 $\alpha(t)$ によって以下の式で表される.

$$
J(t)=\pi R^{4} \alpha(t) / 2 h k \theta
$$

ここで, $R$ と $h$ は試片の半径と厚さである. 粘弾性体 の枚じり変形によって蓄えられた弾性エネルギーの目安 としての定常状態クリープコンプライアンス $J_{\mathrm{e}}^{0}$ および
ねじり変形によって散逸されたエネルギーの目安として の定常粘度 $\eta$ は, 測定されたコンプライアンス $J(t)$ か ら, 以下の二つの式の外挿を行うことによって求められ る。

$$
1 / \eta=\lim _{t \rightarrow \infty} \mathrm{d} J(t) / \mathrm{d} t
$$

及び，

$$
J_{\mathrm{e}}^{0}=\lim _{t \rightarrow \infty}[J(t)-t / \eta]
$$

しかし，この外挿を精度よく行うためには，定常状態の 流動が得られる十分に長時間の測定が必須であるが，実 験的には定常状態が得られたとの保証を得ることは難し い. 本研究では高分子材料の粘弾性測定においてしばし

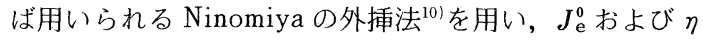
を推定した。

$$
\begin{aligned}
1 / \eta & =\lim _{1 / t \rightarrow 0} J(t) / t \\
& =\lim _{1 / t \rightarrow 0} m J(t) / t \\
m & =\mathrm{d} \log J(t) / \mathrm{d} \log t
\end{aligned}
$$

及び，

$$
J_{\mathrm{e}}^{0}=\lim _{1 / t \rightarrow 0} \mathrm{~d}[J(t) / t] / \mathrm{d}(1 / t)
$$

の二つの式から， $J(t) / t$ 及び $m J(t) / t$ を $1 / t$ に対して プロットし，その二つの関係曲線の交点（すなわち，定 常状態 $m=1$ に対応）の縦座標から $1 / \eta$ を，またその 交点での $J(t) / t$ vs. $1 / t$ 曲線の接線の勾配から $J_{\mathrm{e}}^{0}$ を求 めた。

\section{3. 実験結果}

種々の温度で測定されたクリープコンプライアンス $J(t)$ と時間 $t$ の関係を両対数プロットとして，ピッチ (ベンゼン可溶成分) 及びカーボンブラック分散系（容 積分率 0.096, 重量分率 $13.3 \mathrm{wt} \%$ ) の結果を図2(a) 及び (b) に示した。フフラーの容積分率を異にする各 種の分散系についての $\log J(t)$ vs. $\log t$ 関係から, 時 間-温度の重放合わせの法則に従い, 基準温度 $70.00^{\circ} \mathrm{C}$ で の, マスターカーブを作成した。図 2 からも分かるよう に, 測定の短時間側では, ねじり角度 $\alpha(t)$ の変化が小 さいため $J(t)$ のばらつきが大きく，また定常流動によ り近い，長時間側の方がフィラー量の影響が顕著に見ら れるため, 3 種のフィラーについてのマスターカーブの 長時間側を図 3 にま之めて示した。図中横軸の $a_{\mathrm{r}}$ は時 間軸に沿ってのシフトファクターである.フィラーを少 量加えることによって, $J(t)$ は長時間側にシフトし, 変形流動がより難しくなっていることが分かる.たとえ ば図 3(a) において，容積分率で0.037（5.62 wt\%）加 えるだけで, $J(t)$ は極端に長時間側にシフトしている.

このクリープコンプライアンス $J(t)$ から Ninomiya の外そう法によって定常状態粘度 $\eta$ と定常状態コンプ ライアンス $J_{\mathrm{e}}^{0}$ を求め, カーボンブラック分散系につい 

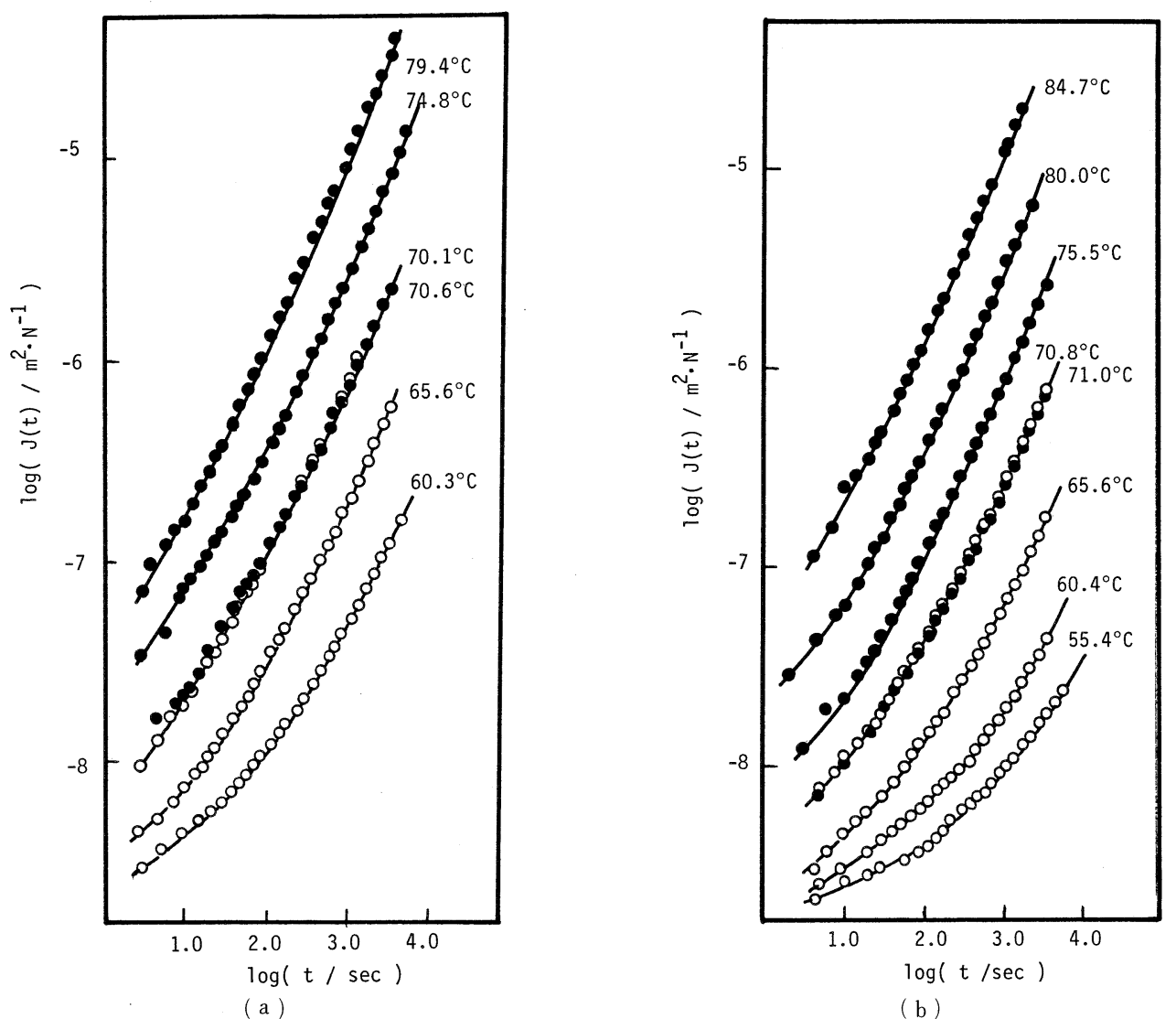

Fig. 2. Creep compliance $J(t)$ measured at different temperatures.

(a) pitch, (b) pitch-carbon black disperse system (volume fraction $\phi=0.096$ )

$\bigcirc: 10 \mathrm{~mm}$ diameter-disk, $: 15 \mathrm{~mm}$ diameter-disk

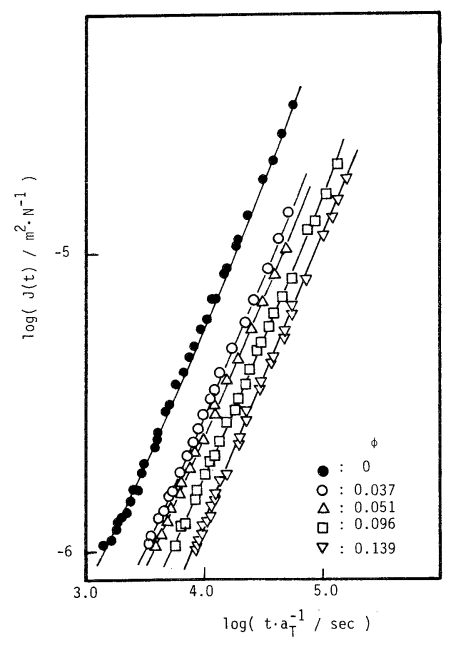

(a)

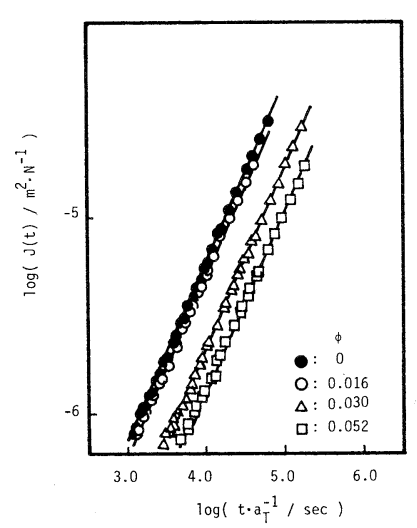

( b )

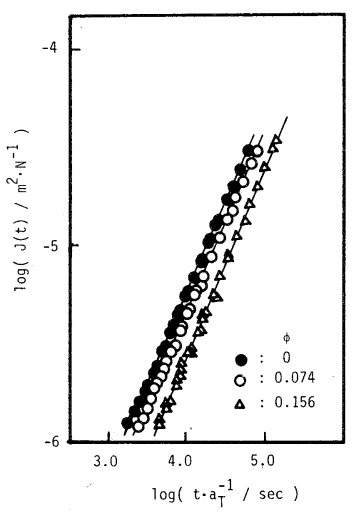

(c)

Fig. 3. Master curves at $70.00^{\circ} \mathrm{C}$ for different disperse systems.

(a) pitch-carbon black, (b) pitch-graphitized carbon black, (c) pitch-carbon beads 


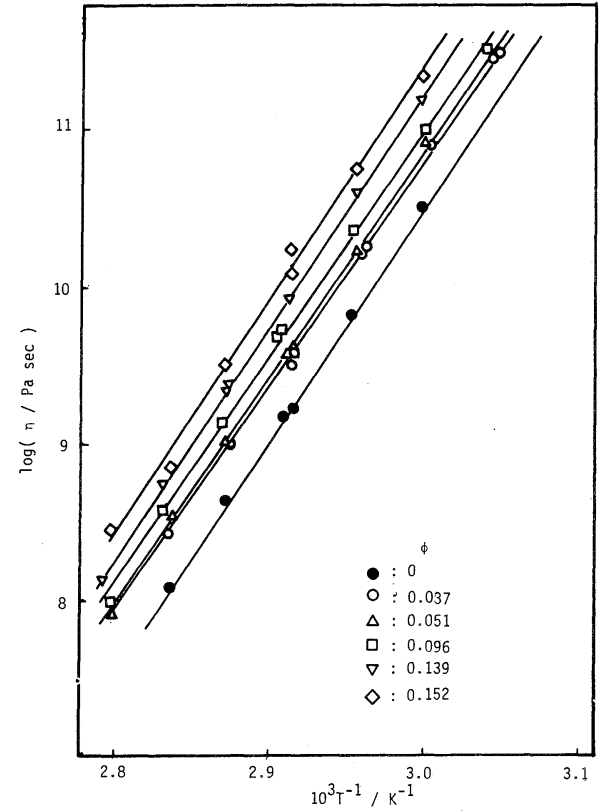

Fig. 4. Temperature dependences of steady state viscosity $\eta$.

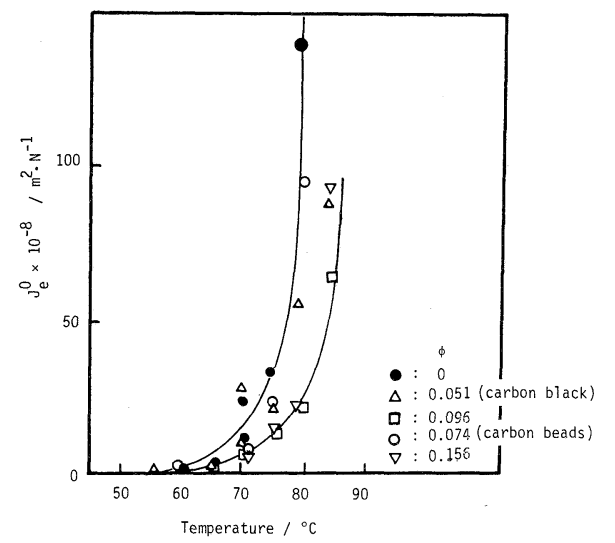

Fig.5. Temperature dependences of steady state compliance $J_{\mathrm{e}}^{0}$.

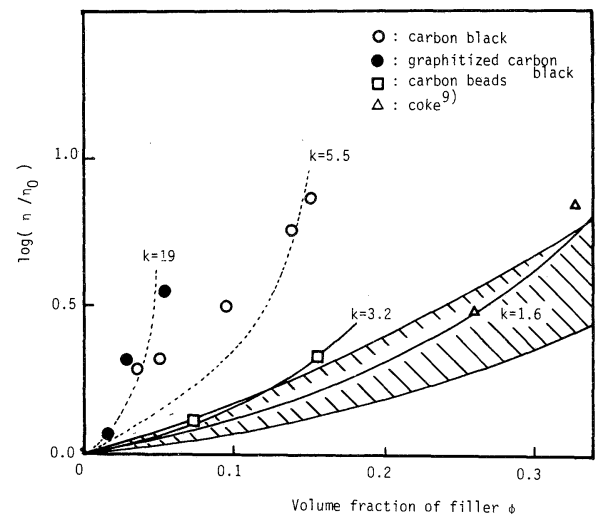

Fig. 6. Relative viscosity $\eta / \eta_{0}$ against volume fraction of filler.
ての粘度 $\eta$ の対数と絶対温度の逆数 $1 / T$ との関係を図 4 に，また，カーボンブラックとカーボンビーズを用い た場合のコンプライアンス $J_{\mathrm{e}}^{0}$ を絶対温度に対してプ ロットしたものを図 5 に示した。

粘度の温度依存性は, 本研究で用いた温度範囲では, 図 4 に示されているように, 直線的で, アレニウス型で 近似できる. その勾配から求められる粘性流動のための 活性化エネルギーはいずれの分散系においても $2.8 \times$ $10^{5} \pm 0.1 \mathrm{~J} / \mathrm{mol}$ と一定值であり，マトリックスピッチに よって決まっていると言える。これに対して, 粘度の值 はフィラーの添加によって顕著に大きくなっている．図 6 には, マトリックスピッチの粘度 $\eta_{0}$ に対する分散系 の粘度 $\eta$ の比, すなわち相対粘度 $\eta / \eta_{0}$, の対数をフィ ラ一の容積分率 $\phi$ に対してプロットした。

図中の斜線の領域は一般的な分散系の相対粘度がプ ロットされる領域 ${ }^{11)}$ であり，また， $\Delta$ 印は Sakai' によっ て報告されているピッチーコークス分散系についての結 果である。

定常コンプライアンス $J_{\mathrm{e}}^{0}$ は, 図 5 に示したように, 温度の上昇によって急激に大きくなる.そして, フィラー の添加によってその值は急激に小さくなる.

\section{4. 考 察}

図 6 において，一般的な分散系についての相対粘度の 対数 $\log \left(\eta / \eta_{0}\right)$ の容積分率 $\phi$ 依存性の範囲内（図中の斜 線の領域) に, ピッチーコークス及びピッチーカーボン ビーズ分散系の実験点が入っているのに対して，ピッ チーカーボンブラック分散系の実験点は非常に高い值を 与えている. 斜線領域は回転粘度計と毛細管粘度計に よって, ポリスチレン, ゴムラテックス, ガラス, メチ ルメタクリレートなどをフィラーとした分散系について の結果を含んでおり，分散系一般について予測される関 係と言えよう。剛体球の低濃度懸濁液に関しては Einstein 式,

$$
\eta / \eta_{0}=1+2.5 \phi
$$

が導かれている ${ }^{12\}}$. そして, 高濃度懸濁液に対しては, 粒子間の相互作用を考慮した関係式,

$$
\ln \eta / \eta_{0}=2.5 \phi /(1-k \phi)
$$

が Mooneyによって導かれている ${ }^{13)}$ にここで， $k$ はクラ ウド係数と呼ばれ，フィラ一粒子が見掛け上 $k$ 倍の体 積として流動していることを示す定数である．本研究で 用いたカーボンビーズの粒径は $37 \mu \mathrm{m}$ 以下であり, Sakai $^{9)}$ の用いたコークス粒子の粒径，44〜53 $\mu \mathrm{m}$ 亡大 差ない.そこで，カーボンビーズを含む分散系について クラウド係数 $k$ を求めると 3.2 , コークス分散系につい ては 1.6 であり, カーボンビーズの場合の方がピッチ中 ではより大きなクラウド係数を有する.

これに対して，より小さな粒子径を持つカーボンブ 
Table 1. Distance between filler particles in pitchcarbon beads and pitch-carbon black disperse systems.

\begin{tabular}{|l|c|c|c|}
\hline \multirow{2}{*}{$\begin{array}{c}\text { volume fraction } \\
\text { of filler }\end{array}$} & Carbon beads & \multicolumn{2}{|c|}{ Carbon black } \\
\cline { 2 - 4 } & $\begin{array}{c}\text { Distance between } \\
\text { particles }(\mu \mathrm{m})\end{array}$ & $\begin{array}{c}\text { Distance between } \\
\text { particles }(\mu \mathrm{m})\end{array}$ & $\begin{array}{c}\text { Thickness of } \\
\text { absorbed layer }(\mu \mathrm{m})\end{array}$ \\
\hline 0.037 & 63.4 & 0.52 & 0.11 \\
0.051 & 53.2 & 0.43 & 0.09 \\
0.096 & 36.1 & 0.34 & 0.06 \\
0.139 & 27.6 & 0.22 & 0.05 \\
0.152 & 25.7 & 0.21 & 0.05 \\
\hline
\end{tabular}

ラックを分散させた場合の相対粘度は一般的な範囲には なく，非常に大きい值である，その容積分率 $\phi$ 依存性 は一つの Mooney 式で近似することはできなかったが, 強いてクラウド係数を求めるとすれば, 図中に示したよ うに，5.5〜19 の範囲の大きな值となる.このことは, ピッチーカーボンブラック分散系では一般的な固液分散 系とは異なり，マトリックスとフィラ一粒子間, さらに はフィラー粒子同士の間にはかなり強い相互作用が働ら いていると考えなければならないことを示している.

そこで, 同様に球形を持ったフィラ一粒子であるカ一 ボンビーズとカーボンブラックについて, 容積分率の関 数としてフィラー粒子の間隔を計算して, 表 1 に示した. また，カーボンブラックについては，その相対粘度の実 測值から，その表面にできているであろうマトリックス ピッチの吸着層の厚さを見積もってみた。すなわち，例 えば容積分率 $\phi$ が 0.096 の場合を考えると，その相対 粘度はほぼ 0.5 となっている。これに対して，一般的な 分散系の領域にあるフィラーとマトリックスとの間に強 い相互作用が無いと仮定できる場合のピッチ-コークス 分散系で 0.5 の相対粘度を与える容積分率は約 0.26 で ある. $\phi=0.096$ において, カーボンブラック粒子の単 位体積当たりの個数は $6.8 \times 10^{18}$ 個であり，これだけの 個数で $\phi=0.26$ を得るためには粒子径が $0.42 \mu \mathrm{m}$ であ ることが必要である。しかし，カーボンブラックの実際 の粒径が $0.3 \mu \mathrm{m}$ であるから，吸着層の厚さは約 0.06 $\mu \mathrm{m}$ と推定される. 同様の計算を各容積分率について行 い, 表 1 中に示した.この計算結果は, 容積分率が小さく, フィラー粒子間隔が大きいほど，吸着層は厚くなってい ると予想されることを示している．このことは，図 6 に おいて, カーボンブラックの容積分率が小さいほどその 添加による相対粘度の増大は顕著であること，言い換え れば，容積分率が小さいほど Mooney 式のクラウド係 数が大きくなければならないことと定性的に一致してい る.

カーボンブラックの表面には，その生成過程で生じた 各種のラジカルが存在しており ${ }^{14)}$, また, 各種の吸着層
も生成している。それらがマトリックスとして用いた ピッチとの相互作用を助長しているとも考えられる.

カーボンブラックを $3000^{\circ} \mathrm{C}$ 付近の高温に加熱処理す ることによって, これらの表面層を取り除き, また炭素 六角網面を成長させることによりカーボンブラック粒子 表面は網平面で取り囲まれた多面体となることが知られ ている，そこで，高温に加熱処理したサーマルブラック を用いた分散系の粘弾性を測定した。しかし，図 5 及び 6 中に示したように, 定常状態コンプライアンス, 粘度 ともに未処理サーマルブラックを用いた場合と差はな く, その添加によって, 粘度は著しく増加し, コンプラ イアンスは減少した。このことはピッチーカーボンブ ラック分散系においては, 上で議論したマトリックスフィラ一間の相互作用に加えて, フィラ一粒子同士の相 互作用も考慮しなければならないことを示唆している.

\section{5. 結言}

本研究において, カーボンブラックがマトリックス ピッチと強い相互作用をもち，カーボンペーストとして 特異な挙動を示すことを粘性, 弾性の両面から明らかにし た.

今後は更に, それらの温度依存性変化の測定などを通 して，これら分散系粘弾性挙動の理解を深めていく必要 があろう。

謝 辞 本研究の研究費の一部は文部省科学研究費一般研 究A（No.59430041）によった.

\section{文献}

1) M. Sakai and M. Inagaki, Carbon, 19, 37 (1981).

2) M. Sakai, M. Yosihara and M. Inagaki, Carbon, 19, 83 (1981).

3) M. Sakai, T. Kida and M. Inagaki, J. Mater. Sci., 19, 2651 (1984).

4) M. Sakai, T. Sogabe, H. Kitagawa and M. Inagaki, Carbon, 21, 601 (1983).

5) M. Sakai, K. Sasaki and M. Inagaki, Carbon, 21, 593 (1983).

6) G. Bhatia, Carbon, 11, 437 (1973); 14, 315 (1976); 14, 319 (1976).

7) G. Bhatia, R. K. Aggarwal, C. S. Chari and G. C. Jain, Carbon, 15, 219 (1977).

8) M. Sakai, Carbon, 17, 131 (1979).

9) M. Sakai, Carbon, 17, 145 (1979).

10) K. Ninomiya, J. Phys. Chem., 67, 1152 (1963).

11) D. G. Thomas, J. Colloid Sci., 20, 267 (1965).

12) A. Einstein, Ann. Phys, , 19, 289 (1906); 34, 591 (1911).

13) M. Mooney, J. Colloid Sci., 6, 162 (1951).

14) J. -B. Donnet and A. Voet, "Carbon Black", Marcel Dekker, New York (1976). 